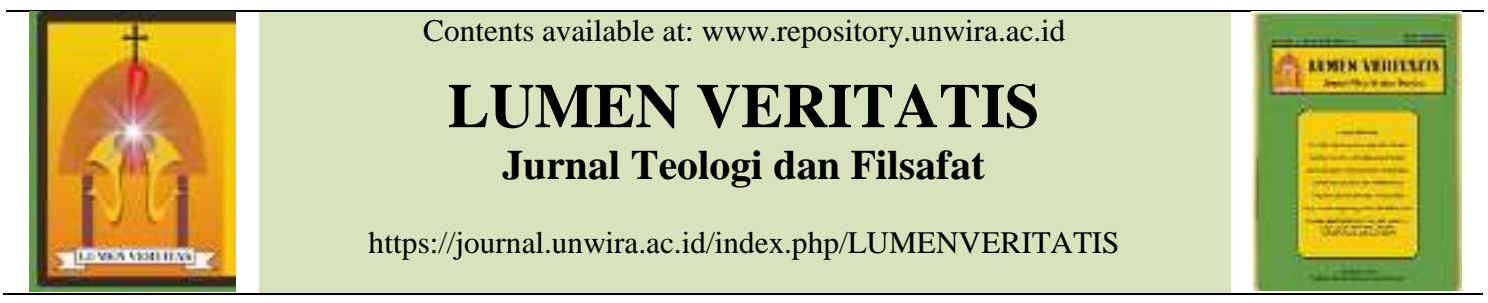

Original article

doi: 10.30822/lumenveritatis.v10i1.207

\title{
KONSEP KEADILAN (IUSTITIA) PERSPEKTIF ST. THOMAS AQUINAS DAN RELEVANSINYA BAGI PEMAKNAAN SILA V PANCASILA
}

\author{
Giovanni Aditya Arum \\ Program Studi Ilmu Filsafat, Fakultas Filsafat, Universitas Katolik Widya Mandira \\ Email: adityaarum1992@gmail.com
}

\begin{abstract}
In principle justice touches the human nature as social animal. The discourse of justice has become an important theme in social and political philosophy all the times. St. Thomas Aquinas is one of the philosophers who pays much attention on this theme. In Summa Theologiae, he spent a lot of pages to explain justice as one of the cardinal virtues. Inspired by Aristotle, he defined justice as "a habit whereby a man renders to each one his due by a constant and perpetual will." This essay wants to explain the discourse of justice according to St. Thomas Aquinas and to compare it with the concept of justice in fifth principle of Pancasila. The writter uses the relevancy study to get the convergency idea between two different ideas of justice. This essay will explore both concept of justice by St. Thomas Aquinas and Pancasila perspective. There are at least some convergency ideas between those two. But the pressure point is the concept of bonum commune. Pancasila as the Philosophische Grondslag of Indonesia as like as St. Thomas Aquinas' idea of justice emphasizes the common good (bonum commune) as the very end of Indonesia nation. Reflecting on these convergency ideas, we can find some relevant discourses concerning justice in socio-political life of Indonesian people, i.e: law, politic, and religion. In the end of this essay, the writer gives a critical thought to the tendency of the liberalism pathology in social life.
\end{abstract}

Keywords: keadilan, Pancasila, hak, bonum commune

\section{Pendahuluan}

Keadilan merupakan sebuah ide yang senantiasa aktual dan relevan dalam panorama perkembangan peradaban manusia. Hal ini secara khusus menyentuh kodrat manusia sebagai animal sociale dan animal politicum. Defenisi klasik keadilan sebagai "suum cuique tribuere; to give everybody his own," telah menunjukkan bahwa keadilan berhubungan dengan relasi antarmanusia.

Dari sekian banyak filsuf yang merefleksikan tema keadilan, salah satunya adalah St. Thomas Aquinas. Ia memetakan keadilan dalam konstelasi relasi sosial antarmanusia. Keadilan 
mengarahkan manusia dalam relasinya dengan sesama yang lain (ad alterum). ${ }^{1}$

Pancasila merupakan jantung seluruh kehidupan berbangsa dan bernegara masyarakat Indonesia. Sebagai dasar filsafat (Philosofische Grondslag) negara, Pancasila mengandung konsekuensi setiap aspek penyelenggaraan negara dan semua sikap serta tingkah laku bangsa Indonesia dalam bermasyarakat, berbangsa dan bernegara harus berdasarkan pada nilainilai Pancasila. Internalisasi dan aktualisasi nilai-nilai Pancasila yang sangat luhur, seperti: nilai Ketuhanan, Kemanusiaan, Persatuan, Kerakyatan dan Keadilan dalam diri tiap masyarakat Indonesia merupakan tanggung jawab yang sangat fundamental untuk diupayakan demi terwujudnya bonum commune.

Namun, factum non fictum, keadilan sosial bagi seluruh rakyat Indonesia sebagai cita-cita luhur bangsa belum mampu diwujudkan secara komprehensif. Dalam hidup bermasyarakat, nilai luhur keadilan ini

${ }^{1}$ Sancti Thomae de Aquino, Summa Theologiae, II-II, Q. 57, a. 1, Resp.Cf. I-II, Q. 60, a. 2. Cura et studio Sac. Petri Carmello, Sacrae Theologiae et Philosophiae doctoris, cum textu ex recensione Leonina Pars II $^{\mathrm{a}} \mathrm{II}^{\mathrm{ae}}$, kerap kali dinodai dengan kedok kepentingan individual yang egoistik. Cita-cita masyarakat yang sejahtera dalam cermin bonum commune telah banyak dihancurkan dengan konflikkonflik yang justru bermula dari titik ketidakadilan.

Tulisan ini akan menelaah konsep keadilan perspektif St. Thomas Aquinas dan irisannya dengan konsep keadilan dalam Sila V Pancasila. Konvergensi pemikiran dari dua tradisi pemikiran yang berbeda ini (khazanah pemikiran Barat dan Timur) akan mengantar kita untuk menelaah dan memaknai dimensi kehidupan sosial bangsa Indonesia dalam konstelasi nilai keadilan demi terwujudnya kesejahteraan umum sebagai amanat konstitusi negara kita.

\section{Konsep keadilan (iustitia) perspektif St. Thomas Aquinas}

\section{Defenisi keadilan (iustitia)}

St. Thomas Aquinas dalam Summa Theologiae parsSecunda Secundae, Questiones 58 articulis 1 dengan tegas

Marietti Editori Ltd., 1962. Selanjutnya buku ini sebagai sumber utama dan akan disingkat $\boldsymbol{S T}$., II-II, dan diikuti dengan nomor quaestiones. 
mendefenisikan keadilan (iustitia) sebagai berikut: "Iustitia est habitus secundum quem aliquis constanti et perpetua voluntate ius suum unicuique tribuit."2 Definisi ini secara khusus merujuk pada defenisi Aristoteles yang mengatakan bahwa: "Justice is a habit whereby a man is said to be capable of doing just actions in accordance with his choice."3

Keadilan (iustitia) sebagai suatu kebajikan memiliki proria materia yang terdiri atas pelbagai hal yang berkaitan dengan relasi manusia dengan sesama yang lain (ad alterum). ${ }^{4}$ Keterkaitan antara keadilan dengan objeknya terangkum dalam ungkapan: ius suum unicuique tribuens; memberikan kepada setiap orang apa yang menjadi haknya. Poin penting berikutnya yang terkandung dalam defenisi keadilan adalah penyebutan term ius (hak). Hak dalam pandangan St. Thomas Aquinas dipandang sebagai obiectum proprium dari keadilan. Hal ini menunjukkan

${ }^{2} S T$., II-II, Q. 58, a. 1, Resp. [Keadilan adalah kebiasaan dimana seseorang dengan kehendak yang konstan dan tetap memberikan kepada setiap orang apa yang menjadi haknya.]

${ }^{3}$ Aristotle, NE., V. 5, 1. Cf. ST., II-II, Q. 58, a.1, Resp. [Keadilan adalah suatu kebiasaan di mana seseorang bahwa tindakan atau pelaksanaan keadilan itu seharusnya didahului oleh tindakan lainnya yang dengan tegas menunjukkan hak seseorang untuk melakukannya. Dari sini dapat disimpulkan bahwa hak dan keadilan itu mempunyai hubungan yang erat satu sama lain. Hak yang dimiliki oleh setiap individu melekat pada kodrat manusia sendiri. Jadi semata-mata bukan berasal dari luar diri manusia. ${ }^{5}$

\section{Konsep keadilan umum (iustitia generalis)}

Keadilan secara esensial mengarahkan manusia kepada kebaikan umum (bonum commune), karena merujuk pada relasi sosial antar-individu. Segala kebajikan dapat menyinggung pada keadilan sejauh ia terarah kepada bonum commune sebagai tujuannya. Dalam konteks pemahaman inilah, keadilan disebut sebagai sebuah kebajikan umum (virtus generalis). ${ }^{6}$

Selain itu, hukum (lex) secara hakiki terarah kepada kebaikan bersama

dikatakan mampu melakukan perbuatan-perbuatan adil dalam persesuaian dengan pilihannya.]

${ }^{4}$ Cf.ST., II-II, Q. 58, a. 2.

${ }^{5}$ E.Sumaryono, Etika Profesi Hukum; Norma-Norma Bagi Penegak Hukum, (Yogyakarta: Kanisius, 1995),hlm. 122.

${ }^{6} \mathrm{ST}$., II-II, Q. 58, a. 5. Resp. 
(bonum commune). Mengikuti pendapat Aristoteles tentang kebahagiaan sebagai telos atau tujuan ultim dari kehidupan manusia, St. Thomas Aquinas mengatakan bahwa demikian pula hukum hendaknya secara prinsipil terarah kepada kebahagiaan. "Unde oportet quod lex maxime respiciat ordinem qui est in beatitudinem." ${ }^{, 7}$ Dan kebahagiaan sebagai kebaikan umum (bonum commune) merupakan tujuan tertinggi dari penerapan hukum. "Et ideo omnis lex ad bonum commune ordinatur." 8

Titik tuju bonum commune dari keadilan umum (iustitia generalis) maupun hukum (lex) yang identik inilah yang kemudian oleh St. Thomas Aquinas disebut dengan istilah keadilan hukum atau keadilan legal (iustitia legalis). Keadilan legal menata seluruh aktivitas manusia kepada kebaikan tertinggi seturut hukum;"'la giuztitia legale ordina tutte le attività umane al bene comune secondo le leggi.",

${ }^{7}$ ST., I-II, Q. 90, a. 2. Resp.Cf. Dino, Bigongiari (ed.), The Political Ideas of St. Thomas Aquinas, (New York: Hafner Publishing Company, Inc., 1953),hlm. 6. [Hukum secara prinsipil harus memperhatikan relasi dengan kebahagiaan.]

${ }^{8}$ ST., I-II, Q. 90, a.2. Resp. Cf.R.W. Dyson (ed.), Aquinas Political Writings, (New York: Cambridge University Press, 2002), hlm. 80. [Setiap hukum terarah kepada kebaikan umum (bonum commune).]

\section{Konsep keadilan khusus (iustitia specialis)}

\section{a. Iustitia commutativa}

Keadilan komutatif (iustitia commutativa) didasarkan pada tatanan relasi dalam masyarakat, yakni pola relasi antar-bagian atau antar-individu dalam masyarakat. St. Thomas Aquinas menjelaskan tatanan hubungan yang mendasari keadilan komutatif sebagai berikut: "Unus quidem partis ad partem; cui similis est ordo unius privatae personae ad aliam. Et hunc ordinem dirigit commutativa iustitia, quae consistit, in his quae mutou fiunt inter duas personas ad invicem." 10

Keadilan komutatif (iustitia commutativa) disebut juga keadilan tukar. Jenis keadilan ini berkonsentrasi pada relasi timbal balik antara dua individu, atau secara partikular nampak dalam hal jual-beli atau dalam perdagangan. Dengan kata lain, bentuk keadilan komutatif di sini pada dasarnya

${ }^{9}$ Raimondo Spiazzi, Principi Di Etica Sociale, (Bologna- Italia: PDUL Edizioni Studio Domenicano, 1989),hlm. 118

${ }^{10}$ ST., II-II, Q. 61, a. 1. Resp. [Pada tempat yang pertama, ada hubungan antarbagian; yangmana menghubungkan relasi antara kepentingan individual seorang pribadi dengan pribadi yang lainnya. Relasi ini diatur oleh keadilan komutatif, yang memperhatikan tentang relasi timbal balik antara dua pribadi]. 
merupakan relasi primer antara individu manusia yang satu dengan individu manusia yang lain. Transaksi 'pertukaran' (exchanges) merupakan term kunci dalam bentuk keadilan komutatif ini.

\section{b. Iustitia distributiva}

Keadilan ini merupakan suatu bentuk keadilan yang menata hubungan antara masyarakat secara keseluruhan atau negara dengan individu sebagai warga masyarakat. Dalam hubungannya dengan sistem pemerintahan, maka keadilan ini lebih mengacu kepada peran sistem pemerintahan atau pemerintah itu sendiri dalam mendistribusikan hak-hak dan kewajiban-kewajiban secara adil dan proporsional bagi setiap anggota masyarakat sesuai dengan peran dan statusnya dalam kesatuan masyarakat. Hal ini diungkapkan oleh St. Thomas Aquinas sebagai berikut: "Alius ordo attenditur totius ad partes, et huic ordini assimilatur ordo eius quod est commune ad singulas personas. Quem quidem

${ }^{11}$ ST., II-II, Q. 61, a. 1. Resp. [Di tempat yang lain, ada hubungan antara keseluruhan terhadap bagianbagiannya, yang menghubungkan relasi keteraturan dari apa yang menjadi milik komunitas dalam hubungan dengan tiap-tiap pribadi. Hubungan ini diatur ordinem dirigit iustitia distributiva, quae est distributiva communium secundum proportionalitatem." 11

Dalam keadilan distributif, kebaikan-kebaikan umum didistribusikan seturut status dan perannya dalam komunitas tertentu di mana pribadi manusia itu tinggal. Dalam negara Aristokrasi status ini dinilai dari kebajikan, dalam negara Oligarki status ini dinilai oleh kekayaan, dan dalam negara Demokrasi dinilai oleh kebebasan. $^{12}$ Jadi, dalam konteks keadilan distributif, keadilan bukan hanya dipandang sebagai suatu kesamaan atau kesetaraan antara satu barang dengan barang yang lain, tetapi dalam proporsi suatu hal atau barang tersebut di hadapan seorang inidividu dalam status dan perannya dalam komunitas masyarakat.

\section{Keadilan (iustitia) dan cinta-kasih (caritas)}

Cinta-kasih adalah sumber utama yang menggerakkan tindakan manusia. Setiap tindakan manusia terarah dan

oleh keadilan distributif, yang mendistribusikan barang-barang umum secara proporsional.]

${ }^{12}$ Hendry J. Schmandt,Filsafat Politik, (Yogyakarta: Pustaka Pelajar, 2002), hlm. 26. 
mencapai kepenuhannya pada cintakasih. "Unde manifestum est quod omne agens, quodcumque sit, agit quamcumque actionem ex aliquo amore". ${ }^{13}$ Dalam konteks ini, posisi keutamaan kasih di hadapan keutamaankeutamaan lainnya menjadi penting. Kasih menjadi "ibu" (mater) dan "akar" (radix) yang melandasi keutamaankeutamaan lainnya.

Dalam pandangan St. Thomas Aquinas, tidak ada pertentangan antara keadilan dan cinta-kasih.Ia mengatakan bahwa: "nothing contrary to the precepts of justice and charity." 14

Caritasmenekankan relasi dengan Allah dan sesama. Kasih kepada Allah (dilectio ad Deum) meluas pada kasih terhadap sesama (dilectio ad fratrem). Caritas tidak hanya tertuju kepada Tuhan semata melainkan meluas sampai pada sesama manusia. St. Thomas Aquinas mengungkapkan bahwa:

\footnotetext{
${ }^{13} S T$., I-II, Q. 28, a. 6, Resp. [Setiap tindakan apapun jenisnya, mencapai kepenuhannya karena cinta-kasih] ${ }^{14}$ Sancti Thomae de Aquino, Summa Contra Gentiles., lib.3, cap. 128, Textum Leoninum emendatum ex plagulis de prelo Taurini 1961 editum ac automato translatum a Roberto Busa SJ in taenias magneticas denuo recognovit Enrique Alarcón atque instruxit. Selanjutnya akan ditulis $\boldsymbol{S C G}$., dan akan diikuti penomoran sebagaimana lazimnya.

${ }^{15}$ ST., II-II, Q. 25, a. 1, Resp. [Sesungguhnya, aspek yang mendasari bahwa sesama kita harus dicintai
}

Ratio autem diligendi proximum Deus est: hoc enim debemus in proximo diligere, ut in Deo sit. Unde manifestum est quod idem spacie actus est quo diligitur Deus, et quo diligitur proximus. Et propter hoc habitus caritatis non solum se extendit ad dilectionem Dei, sed etiam ad dilectionem proximi. $^{15}$

Terdapat relasi yang erat antara keadilan dan cinta-kasih. Apa yang dituntut dari keadilan akan dituntut juga dari cinta-kasih, namun tidak sebaliknya. Itu berarti, cinta-kasih adalahkebajikan yang menyeluruh dan mencakup keadilan, dan tuntutan keadilan merupakan tuntutan minimal cinta-kasih. Hubungan mendasar antara keadilan dan cinta-kasih terletak di dalam kenyataan bahwa setiap kewajiban keadilan merupakan kewajiban cinta-kasih, meskipun tidak setiap kebajikan cintakasih merupakan kebajikan keadilan, karena cinta melampaui keadilan. Jadi, keadilan merupakan kebajikan moral yang tidak pernah dapat berseberangan dengan cinta-kasih. ${ }^{16}$

adalah Allah, karena apa yang harus kita cintai dalam diri sesama kita adalah karena ia mungkin berada dalam Allah. Oleh karena itu, jelas bahwa hal tersebut secara spesifik merupakan aktus yang sama melalui mana kita mencintai Allah, dan melalui mana kita mencintai sesama kita. Konsekuensinya, habitus kasih meluas tidak hanya pada cinta kepada Allah, melainkan juga cinta kepada sesama].

${ }^{16}$ Karl-Heinz Peschke, Etika Kristiani; Jilid III Kewajiban Moral dalam Hidup Pribadi, (Maumere: Ledalero, 2003), hlm. 48-49. 


\section{Konvergensi konsep keadilan Thomas dan konsep keadilan dalam sila V Pancasila}

\section{Konsep keadilan dalam sila $\mathbf{V}$ Pancasila}

a. Hubungan keadilan yang bersifat segitiga

Inti yang terkandung dalam sila

kelima adalah keadilan, yang berarti mengandung pengertian kesesuaian dengan hakikat adil. Konsekuensinya, dalam setiap aspek penyelenggaraan negara harus senantiasa berdasarkan pada nilai-nilai keadilan. Maka dalam realisasinya dalam hidup bersama (masyarakat), bangsa dan negara terdapat tiga macam hubungan keadilan atau disebut juga hubungan keadilan yang bersifat segitiga. Hal ini dapat diuraikan sebagai berikut:

Segi pertama yaitu masyarakat bangsa dan negara sebagai pihak yang wajib memenuhi keadilan terhadap warganya. Hubungan keadilan segi pertama ini disebut keadilan membagikan (keadilan distributif), yaitu masyarakat bangsa dan negara wajib memberikan atau membagikan kepada warganya apa yang menjadi haknya, menurut syaratsyarat, wajib dan kekuasaan yang ada dalam masyarakat, bangsa dan negara tersebut yang harus dipenuhi dalam segala hal.

Segi kedua yaitu warga masyarakat atau warga negara sebagai pihak yang wajib memenuhi keadilan terhadap masyarakat, bangsa atau negaranya. Hubungan keadilan segi kedua ini disebut keadilan untuk bertaat (keadilan legal). Hal ini dapat dipahami karena pada hakikat terwujudnya suatu masyarakat adalah sebagai akibat kehendak bersama dari para warganya. Karena ada kesempatan kehendak bersama maka untuk terwujudnya suatu masyarakat, bangsa dan negara harus ada suatu peraturan yang harus ditaati bersama oleh para warganya. Oleh karena itu, wajib ketaatan dari para warga masyarakat dan warga terhadap masyarakat, bangsa dan negaranya adalah merupakan hak dari setiap masyarakat, bangsa dan negara.

Segi ketiga yaitu berupa hubungan keadilan yang terwujud di antara sesama warga dari masyarakat, bangsa dan negara, dalam artian terdapat wajib timbal-balik untuk saling memenuhi keadilan di antara sesama warga. Hubungan keadilan ini disebut keadilan komutatif. Di dalam kehidupan bersama harus senantiasa terwujud keadilan 
komutatif yaitu memberikan kepada sesama warga masyarakat, bangsa dan negara segala sesuatu yang telah menjadi hak masing-masing, menurut kesadaran nilai antara hal-hal atau barang-barang yang wajib diberikan dan hal-hal atau barang-barang yang wajib diterima sebagai haknya. ${ }^{17}$

\section{b. Unsur-unsur keadilan sosial}

Agar dapat memahami makna unsurunsur keadilan sosial, maka dipandang sangat perlu untuk memahami makna hak dan wajib. Hak adalah kuasa untuk menerima atau melakukan sesuatu yang seharusnya diterima atau dilakukan, yang pada prinsipnya hanya dilakukan oleh pihak atau individu tertentu dan tidak dapat dilakukan oleh pihak lain siapapun juga yang dalam prinsipnya dapat dituntut dengan paksaaan olehnya. Sedangkan wajib adalah beban untuk memberikan atau membiarkan barang sesuatu yang semestinya diberikan atau dibiarkan, yang hanya dilakukan oleh pihak tertentu dan tidak dapat dilakukan oleh siapapun juga, dan yang pada

${ }^{17}$ Prof. DR. H. Kaelan, Negara Kebangsaan Pancasila:Kultural, Historis, Filosofis, Yuridis, dan prinsipnya dapat dituntut dengan paksaan dari padanya. ${ }^{18}$

Hak dan wajib merupakan unsur esensial dalam terwujudnya keadilan. Dalam realitas hidup sosial, kedua unsur ini memainkan peran yang vital dalam menjamin kesejahteraan umum. Tanpa penghargaan terhadap hak, maka akan timbul pelbagai masalah dan konflik, seperti: pemerasan, penindasan, pemaksaan dan tindak kejahatan lainnya. Selain itu, tanpa penegasan akan kewajiban, maka masyarakat akan bertindak semena-mena dan bersikap egois bahkan sampai pada titik meniadakan sesamanya. Oleh karena itu, dengan menjunjung tinggi hak dan kewajiban dalam kehidupan bermasyarakat, berbangsa dan bernegara di Indonesia, maka tujuan keadilan sosial bagi seluruh rakyat Indonesia dapat terwujud.

\section{Konvergensi pemikiran keadilan St. Thomas Aquinas dan sila V Pancasila}

a. Keadilan yang berketuhanan

Dalam pemikiran St. Thomas Aquinas, traktat moral (tractatusmoralis)

Aktualisasinya, (Yogyakarta: Paradigma, 2013),hlm. 401-402

${ }^{18}$ Ibid., hlm. 419-420. 
tidak pernah terpisah dari diskursus traktat teologi (tractatus theologicus). Demikian pula dengan keadilan. Keadilan manusiawi (iustitia humana) sebagai suatu bentuk kebajikan utama (virtus cardinalis) tidak pernah terlepas dari keadilan ilahi (iustitia divina). Merujuk pada St. Agustinus yang mendefenisikan keadilan yang bersifat Teosentris demikian:"justice is love serving God his authority over the things that are subject to him"19, St. Thomas Aquinas memperluas horizon pemikiran ini dengan kritis sebagai berikut: "quod sicut in dilectione Dei includitur dilectio proximi, ut supra dictum est; ita etiam in hoc quod homo servit Deo includitur quod unicuique reddat quod debet."20 Mencintai Allah dengan sendirinya meluas pada cinta terhadap sesama. Dengan demikian, defenisi keadilan sebagai habitus dimana seseorang dengan kehendak yang tetap dan konstan memberikan kepada orang lain apa yang menjadi haknya, termasuk bentuk

${ }^{19}$ St. Agustinus, De Moribus Ecclesiae Catholicae, XV, trans. by Rev. Richard Stothert, M.A, The Morals of Catholic Church, in Philip Schaft (ed.), Nicene and Post-Nicene Fathers Series I Volume 4, (Grand Rapids, MI: Christian Classic Ethereal Library) yang diakses dari www.ccel.org/ccel/shaft/npnf.1024.html as we found it on 24 Juli 2015 12:08:51. pengabdian kepada Tuhan. Oleh karena itu, dapat dipahami bahwa keadilan bersifat Ketuhanan.

Dalam Pancasila, diskursus keadilan tidak bisa dipisahkan dari diskursus Ketuhanan. Sebagaimana Pancasila merupakan suatu kesatuan sistemik, maka sila keadilan sosial bagi seluruh rakyat Indonesia adalah sila keadilan yang berKetuhanan yang Maha Esa, yang berkemanusiaan yang adil dan beradab, yang berpersatuan Indonesia, dan yang berkerakyatan yang dipimpin oleh hikmat kebijaksanaan dalam permusyawaratan/ perwakilan. Jadi, dalam hubungan dengan sila I, keadilan dalam Pancasila adalah keadilan yang berKetuhanan.

Dengan demikian, keadilan yang berKetuhanan menjadi salah satu titik konvergensi pemikiran keadilan dalam konsep St. Thomas Aquinas dan dalam konsep Pancasila. Negara Indonesia bukanlah negara sekuler, melainkan negara yang mengakui adanya Tuhan sebagai Causa Prima. Dalam konstitusi

\footnotetext{
${ }^{20} \boldsymbol{S T}$., II-II, Q. 58, a. 1, ad. 6. [Sebagaimana telah dikatakan bahwa cinta kepada Tuhan termaktub juga cinta terhadap sesama, demikian pula pengabdian terhadap Tuhan termaktub pula pada pemberian terhadap tiap orang apa yang wajib diterimanya].
} 
negara Indonesia dengan jelas disebutkan "Atas berkat rahmat Allah yang Maha Kuasa...” (alinea III) dan “... dengan berdasar kepada Ketuhanan Yang Maha Esa..." (alinea IV).

b. Keadilan yang bersifat segitiga Diskursus keadilan dalam Pancasila dijabarkan dalam tiga macam hubungan keadilan atau disebut juga hubungan keadilan yang bersifat segitiga, yakni: Segi pertama, adalah hubungan keadilan yang disebut dengan keadilan distributif, yaitu masyarakat bangsa dan negara wajib memberikan atau membagikan kepada warganya apa yang menjadi haknya, menurut syarat-syarat, wajib dan kekuasaan yang ada dalam masyarakat, bangsa dan negara tersebut yang harus dipenuhi dalam segala hal. ${ }^{21}$ Segi pertama keadilan ini bersesuaian dengan konsep iustitia distributiva St. Thomas Aquinas.

Segi kedua, adalah hubungan keadilan yang disebut dengan keadilan legal. Setiap warga Indonesia wajib memperjuangkan kebaikan bersama (bonum commune) sebagai cita-cita luhur bangsa dan negara Indonesia. ${ }^{22}$ Segi

${ }^{21}$ Prof. DR. H. Kaelan, Negara Kebangsaan Pancasila, Op.Cit., hlm. 401.

${ }^{22}$ Ibid., hlm. 402. kedua ini berhubungan dengan konsep iustitia generalis St. Thomas Aquinas.

Segi ketiga adalah hubungan keadilan yang disebut dengan keadilan komutatif. Di dalam kehidupan bersama harus senantiasa terwujud keadilan komutatif, yaitu memberikan kepada sesama warga masyarakat, bangsa dan negara segala sesuatu yang telah menjadi hak masing-masing, menurut kesadaran nilai antara hal-hal atau barang-barang yang wajib diberikan dan hal-hal atau barang-barang yang wajib diterima sebagai haknya. ${ }^{23}$ Segi ketiga ini bersesuaian dengan konsep iustitia commutativa St. Thomas Aquinas yang mengkaji keadilan dalam relasi khusus antar-individu dalam masyarakat.

\section{c. Keadilan yang bersifat cinta kasih}

Cinta-kasih (caritas) dalam pandangan St. Thomas Aquinas, tidak bertentangan dengan keadilan. Ia mengatakan bahwa: "nothing contrary to the precepts of justice and charity." 24 Caritas menekankan relasi dengan Allah dan sesama. Kasih kepada Allah (dilectio ad Deum) meluas pada kasih terhadap

\footnotetext{
${ }^{23}$ Ibid.

${ }^{24}$ SCG., lib. 3, cap. 128
} 
sesama (dilectio ad fratrem). Caritas tidak hanya tertuju kepada Tuhan semata melainkan meluas sampai pada sesama manusia. $^{25}$ Keadilan merupakan bentuk cinta-kasih yang berkonsentrasi pada aktus memberikan kepada setiap orang apa yang menjadi haknya. Cinta-kasih (caritas) melampaui dan melengkapi keadilan (iustitia) sebagai salah satu kebajikan moral. Hal ini karena cintakasih (caritas) merupakan forma dari segala bentuk kebajikan.

Jika dianalisis, maka sila-sila pada Pancasila dapat dipetakan dalam dua relasi, yakni: relasi vertikal yang mengatur hubungan antara manusia dengan Tuhan (Sila I), dan relasi horizontal yang mengatur hubungan antara manusia dengan sesamanya (Sila II- V). Driyarkara menempatkan dua bentuk relasi ini dalam konteks filsafat Pancasila dengan bertumpu pada kodrat manusia sebagai kecintaan. ${ }^{26}$ Cinta kasih inilah yang dipandang oleh Driyarkara sebagai landasan pemersatu sila-sila Pancasila. Dalam Pancasila, termuat relasi cinta antara manusia dan Tuhan

${ }^{25}$ Cf. $S T$., II-II, Q. 25, a. 1, Resp.

${ }^{26}$ Driyarkara, "Pancasila dan Religi" dalam A. Sudiarja, et. al., Op.Cit., hlm. 838-839.

${ }^{27}$ Cf. ST., II-II, Q. 25, a. 1, Resp.
(Sila I) dan antar sesama manusia (Sila IIV). Secara umum, pandangan ini sangat bersinggungan dengan pendapat St. Thomas Aquinas tentang cinta-kasih (caritas) sebagai kebajikan teologal terbesar. Caritas tidak hanya tertuju kepada Tuhan semata melainkan meluas sampai pada sesama manusia. ${ }^{27}$ Dengan demikian, keadilan dalam sila V Pancasila merupakan bentuk penjabaran cinta-kasih terhadap sesama.

\section{d. Keadilan yang menghormati hak manusia}

St. Thomas Aquinas dengan tegas mendefenisikan keadilan sebagai berikut: "Iustitia est habitus secundum quem aliquis constanti et perpetua voluntate ius suum unicuique tribuit."28 Hak dalam pengertian hukum (ius), perspektif St. Thomas Aquinas dipandang sebagai obiectum proprium dari keadilan. Defenisi yang menekankan pada hak manusia ini mengungkapkan bahwa keadilan sebagai sebuah kebajikan senantiasa menghormati martabat manusia qua manusia. Dalam konteks pemahaman antropologi St. Thomas Aquinas, martabat manusia melekat pada

${ }^{28}$ ST., II-II, Q. 58, a. 1, Resp. [Keadilan adalah kebiasaan dimana seseorang dengan kehendak yang konstan dan tetap memberikan kepada setiap orang apa yang menjadi haknya]. 
hakekat dirinya sebagai imago Dei (citra Allah). Dengan demikian, pemenuhan hak seseorang dalam bentuk keadilan merupakan bentuk penghormatan terhadap keluhuran martabat manusia.

Keadilan dalam Pancasila juga menekankan respek terhadap hak manusia. Hak dan kewajiban dipandang sebagai unsur-unsur esensial dalam keadilan sosial. Dengan memberikan kepada setiap orang apa yang menjadi haknya, keadilan dalam Pancasila menegaskan keluhuran martabat manusia Indonesia yang dipandang sebagai kesatuan yang bersifat dwi-tunggal, yakni baik sebagai makhluk otonom maupun sebagai makhluk Tuhan.

Notonagoro mengelaborasi konsep keadilan dalam Pancasila dan mengangkat tema mengenai watak manusia Indonesia. Ia mengatakan bahwa: "Pada manusia harus selalu ada kemampuan untuk memberikan kepada diri sendiri dan kepada orang lain apa semestinya, apa yang telah menjadi haknya."29 Aktus menghargai dan menghormati hak sesama merupakan watak khas bangsa Indonesia. Watak

\footnotetext{
${ }^{29}$ Notonagoro, Pancasila Secara Ilmiah Populer,
} (Jakarta: Pantjuran Tudjuh, 1975), hlm. 140. mencerminkan bahwa keadilan menjadi identitas masyarakat Indonesia. Konsep ini sejalan dengan konsep keadilan dalam pemikiran St. Thomas Aquinas yang disebutnya sebagai habitus. Keadilan hendaknya menjadi aktus habitual dan bukannya aktus aksidental. Dalam konteks Pancasila, menghormati hak sesama haruslah senantiasa menjadi watak seluruh masyarakat Indonesia.

\section{Bonum commune sebagai titik konvergensi pemikiran}

St. Thomas Aquinas dengan sangat tegas menempatkan bonum commune sebagai titik tuju dari keadilan (iustitia). Keadilan umum mendapatkan ciri khasnya justeru dalam prospek terhadap bonum commune. Dalam pemahaman St. Thomas Aquinas, kata "keadilan" dimulai dengan suatu obeservasi bahwa seseorang yang melayani suatu komunitas tertentu berarti juga melayani tiap orang (omnibus hominibus) yang tergabung di dalamnya. ${ }^{30}$ Bentuk relasi seseorang terhadap komunitasnya ini dipandang sebagai suatu bentuk relasi antara bagian (pars) terhadap keseluruhan (totus). Dan sebagaimana

${ }^{30} S T$. , II-II, Q. 58, a. 5. Resp. 
"bagian” (pars) merupakan bagian dari keseluruhan (totus), maka kebaikan pribadi (bonum privatum) hanya mungkin lahir dari kebaikan umum (bonum commune). Dengan kata lain, keadilan justeru mendapatkan maknanya yang tegas dalam keterarahan pada bonum commune.

Penegasan bonum commune yang mewarnai pemikiran tentang keadilan (iustitia), diungkapkan St. Thomas Aquinas ketika ia berbicara tentang seorang pemimpin yang adil. Dengan jelas ia mengatakan tentang pemimpin yang tidak adil demikian: "Si vero non ad bonum commune multitudinis, sed ad bonum privatum regentis regimen ordinetur, erit regimen iniustum atque perversum." "31 Pemerintah yang hanya mencari interese pribadi dan mengabaikan kepentingan umum (bonum commune) maka pemerintah itu sendiri tidaklah adil. Prospek terhadap bonum communelah yang menjadikan seorang pemimpin dapat dipandang sebagai pemimpin yang adil.

${ }^{31}$ Sancti Thomae de Aquino, De Regno ad Regem Cypri, lib. I. Cap. 2, Textum Taurini 1954 editum ac automato translatum a Roberto Busa SJ in taenias magneticas denuo recognovit Enrique Alarcón atque
Dalam konteks keadilan Sila V Pancasila, Notonagoro menjelaskan bahwa bonum commune atau kesejahteraan bersama jauh melampaui bonum privatum atau kesejateraan perseorangan. Ia mengatakan: "Adapun asas kekeluargaan mengajarkan (antara lain) bahwa kepentingan dan kesejahteraan bersamalah yang harus diutamakan, dan bukan kepentingan atau kesejahteraan orang-seorang." 32 Dengan demikian, asas kekeluargaan sebagai identitas bangsa Indonesia memiliki respek yang sangat besar terhadap kesejahteraan umum (bonum commune). Hal ini juga membuktikan bahwa liberalisme-individualis yang sangat menekankan kebebasan dan kepentingan pribadi tidak sesuai dengan prinsip kekeluargaan dan gotong-royong yang menjadi kekhasan identitas bangsa Indonesia.

Konsep negara kekeluargaan menempatkan kesejahteraan umum (bonum commune) di atas interese pribadi. Hal ini sesuai dengan pandangan St.Thomas Aquinas mengenai negara

instruxit. Selanjutnya akan ditulis De Regno dan diikuti penomoran lazimnya.

${ }^{32}$ Notonagoro, Op.Cit., hlm. 154. 
sebagai suatu bentuk societas perfecta di dunia yang mendapatkan legitimasi etisnya justeru pada keadilan yang terarah kepada bonum commune. ${ }^{33}$ Selain itu, bunyi sila V: "Keadilan sosial bagi seluruh rakyat Indonesia" dengan jelas mengandung makna bahwa keadilan di Indonesia diupayakan bagi kepentingan seluruh rakyat Indonesia (bonum commune), bukan hanya kepentingan orang-perorangan ataupun golongangolongan tertentu. Dengan demikian, bonum commune merupakan titik konvergensi pemikiran keadilan dalam konsep St. Thomas Aquinas dan dalam Pancasila.

\section{Pemaknaan keadilan dalam pelbagai diskursus kehidupan}

\section{Keadilan dan hukum}

Ius quia iustum. Adil adalah unsur

konstitutif dari hukum; tanpa ada adil di dalamnya maka tidak ada hukum, atau, kalaupun dia ada sebagai hukum namun sebenarnya tidak lagi memiliki sifat mewajibkan sebagai hukum. ${ }^{34}$ Adalah suatu contradictio in terminis

\footnotetext{
${ }^{33}$ Paul J. Weithman, "Complementarity and Equality in The Political Thought of Thomas Aquinas," dalam Michael A. Fahey, SJ, et. al., (eds.), Theological Studies, Juni 1998, Vol. 59, No. 2, hlm. 287.
}

(kontradiksi dalam pengertian itu sendiri) kalau hukum itu tidak adil, karena isi pengertian hukum itu sendiri adalah tentang yang adil. Konsekuensi pandangan hukum sebagai ius adalah bahwa hukum melebihi negara sebab hukum berkaitan langsung dengan manusia sebagai manusia. Memang hukum terdapat dalam negara dan ditetapkan oleh negara, tetapi negara bukan hanya tidak boleh melainkan juga tidak berwenang untuk membentuk suatu tatanan hukum yang tidak adil. ${ }^{35}$

Mengenai diskursus hukum, St. Thomas Aquinas menjelaskan tentang eksistensi hukum kodrat (lex naturalis). ${ }^{36}$ Hukum kodrat merupakan sistem kewajiban moral yang menandakan bahwa ada tuntutan fundamental dalam hidup manusia qua manusia yang sebagai makhluk yang memiliki dua facultas yakni intelek (intellectus) dan kehendak (voluntas). Bagi St. Thomas Aquinas, hidup menurut kodrat tidak lain merupakan hidup menurut kehendak Tuhan, karena per naturam kodat

\footnotetext{
${ }^{34}$ Norbertus Jegalus, Hukum Kata Kerja; Diskursus Filsafat tentang Hukum Progresif, (Jakarta: Obor, 2011), hlm. 17.

${ }^{35}$ Ibid., hlm. 18-19.

${ }^{36}$ ST., II-II, Q. 91, a. 2; Q. 94.
} 
manusia itu diciptakan oleh Tuhan sendiri. Hukum kodrat (lex naturalis) juga berderivasi pada hukum positif atau hukum manusia (lex humana). ${ }^{37}$ Namun, asasnya adalah hukum manusia (lex humana) tidak boleh bertentangan dengan hukum kodrat (lex naturalis).

Dalam penjelasan UUD 1945 ditegaskan: Indonesia ialah negara yang berdasar atas hukum (rechtsstaat). Dalam hubungan dengan diskursus Pancasila sebagai dasar hukum Indonesia, maka acuan penerapan hukum di Indonesia sejatinya bersumber pada nilai-nilai Pancasila. Salah satu nilai Pancasila adalah keadilan (sila V). Oleh sebab itu, diskursus komprehensif tentang hukum di Indonesia tidak dapat dipisahkan dengan diskursus keadilan. Hukum dalam dirinya sendiri haruslah adil sehingga mampu membawa seluruh rakyat Indonesia menuju bonum commune.

Fakta penerapan hukum di Indonesia kerap kali tidak dapat terhindar dari polemik tentang keadilan. Resiko mereduksi hukum dalam undang-undang atau gejala legalisme hukum yang kian mengemuka perlu dikritisi dengan diskursus mengenai keadilan. Banyak kasus pelanggaran hukum dalam kehidupan masyarakat dijerat dengan hukuman, yang di satu sisi mampu menjawabi tuntutan hukum tertulis (undang-undang) namun, adakalanya di sisi yang lain justeru mengingkari nilai keadilan. Padahal, hukum yang sejati haruslah benar-benar adil.

Mengenai dialektika hukum dan keadilan, maka diskursus epikeia yang dibicarakan oleh St. Thomas Aquinas mendapat relevansi pemaknaannya. Bahwasanya, berhadapan dengan situasisituasi khusus, aspek kewajaran hukum (epikeia) tidak boleh dipinggirkan. Itulah sebabnya, Satjipto Rahardjo mengingatkan bahwa "masih ada logika lain yang perlu dimasukkan manakala diinginkan untuk membaca suatu peraturan dengan lebih baik. Logika peraturan adalah salah satu saja, kerena masih ada logika peraturan sosial (social reasonableness). Pada saat ini kita mempertimbangkan, apakah yang ingin dilakukan sudah sesuai dengan kepatutan dalam masyarakat, kita memasuki logika

${ }^{37} \boldsymbol{S T}$., II-II, Q. 91, a. 3; QQ. 95-96. 
kepatutan itu." Epikeia adalah bagian dari keadilan yang dinyatakan secara umum sedemikian rupa sehingga keadilan bagaimana pun tetap bagian tak terpisahkan dari hukum. Itu berarti, epikeia adalah bagian dari keadilan. ${ }^{38}$

\section{Keadilan dan politik}

Wacana keadilan tidak pernah dapat dipisahkan dari kehidupan politik, sebab tujuan politik yang sejati yakni bonum commune hanya dapat dicapai dengan keadilan. Dengan kata lain, berbicara tentang eksistensi politik tidak pernah dapat memarginalkan diskursus keadilan.

Demikian pula dengan gagasan keadilan perspektif St. Thomas Aquinas yang memiliki relevansi besar bagi kehidupan politik seluruh bangsa manusia, khususnya dalam konteks negara Indonesia. Baik keadilan komutatif yang menjamin relasi yang adil antarwarga negara, keadilan distributif yang menjamin relasi antara Negara (pemerintah) dan warga negara, maupun keadilan legal yang menjamin relasi antara warga negara dengan Negara,

\footnotetext{
${ }^{38}$ St. Thomas Aquinas sendiri memetakan epikeia dalam diskursus mengenai bagian kuasi-potensial dari keadilan (partibus quasi potentialibus iustitiae) $\mathbf{C f}$. ST., II-II, Q. 80, namun, dalam konteks umum St. Thomas Aquinas sendiri menjelaskan bahwa epikeia
}

sejatinya perlu diimplementasikan dalam tiap sendi kehidupan politik di negara Indonesia demi terwujudnya kesejahteraan umum sebagai cita-cita luhur bangsa dan negara Indonesia.

Permasalahan yang urgen mengenai keadilan dalam kehidupan politik suatu negara adalah diskursus mengenai keadilan distributif. Negara wajib mendistribusikan kebijakan publik yang seadil-adilnya bagi para warga negara demi menjamin kesejahteraan umum. Bila dihubungkan dengan cita-cita bangsa dan negara untuk menciptakan masyarakat adil dan makmur, keadilan distributif itu tidak lain justeru merupakan bentuk penghormatan terhadap person (acceptio personarum) dan keluhurannya (dignitas). ${ }^{39}$ Tentang penghormatan terhadap person, St. Thomas Aqunias menyatakan bahwa penghormatan itu terwujud bilamana ada sesuatu diberikan/dibagikan kepada

lebih terarah kepada keadilan legal (keadilan hukum) sehingga dalam pengertian ini, epikeia termasuk dalam bagian subjektif dari keadilan (de partibus subiectivis iustitiae) Cf. ST., II-II, Q. 120, a. 2.

${ }^{39}$ E. Sumaryono, Op.Cit., 125. 
seseorang sebanding dengan yang seharusnya ia terima. ${ }^{40}$

Selain itu, perlu juga ditekankan mengenai pribadi pemerintah yang adil. Praktek korupsi, kolusi dan nepotisme selama ini telah menjadi titik kelam yang mengaburkan cita-cita kesejahteraan umum. St. Thomas Aquinas sendiri menguraikan bahwa jika pemerintah tidak berupaya mencapai kesejahteraan umum sebagai tujuan tertinggi dan berorientasi pada kepentingan privat yang egoistik maka tidak tercapai keadilan. ${ }^{41}$ Oleh karena itu, pemerintah sebagai wakil rakyat dan struktur negara perlu menghayati dan mengimplementasikan nilai keadilan dalam hidup dan dalam penerapan kebijakan publik yang mampu membawa kesejahteraan umum bagi seluruh lapisan masyarakat Indonesia.

\section{Keadilan dan agama}

Wacana kebajikan moral tidak pernah terlepas dari persoalan teologis. Tuhan sebagai Causa Prima sekaligus Ultissima Finem dari seluruh kebajikan

${ }^{40}$ Cf.Etienne Gilson, Thomism; The Philosophy of Thomas Aquinas, (Toronto-Canada: Pontifical Institute of Mediaeval Studies, 2002), hlm. 353.

${ }^{41}$ De Regno, I, 2.Cf.Sancti Thomae de Aquino, Sententia Libri Politicorum, trans. by Richard J. manusia karena kebajikan mendapat penegasan artinya sejauh terarah kepada kebaikan (bonum). Dan Kebaikan Tertinggi (Summum Bonum) adalah Tuhan sendiri. Iustitia humana (keadilan manusiawi) berakar pada iustitia divina (keadilan ilahi).

Pancasila memiliki kesatuan sistem filsafat. Sila yang satu terkait erat dengan sila yang lain. Oleh karena itu, hakikat filosofis sila keadilan sosial bagi seluruh rakyat Indonesia adalah keadilan sosial yang ber-Ketuhanan yang Maha Esa, yang berkemanusiaan yang adil dan beradab, yang berpersatuan Indonesia, yang berkerakyatan yang dipimpin oleh hikmat kebijaksanaan dalam permusyawaratan/ perwakilan. ${ }^{42}$ Tuhan dipandang sebagai Causa Prima dan dasar tertinggi dari hakikat sila lainnya yakni manusia, satu, rakyat dan juga adil. Dengan demikian, rakyat Indonesia harus juga memenuhi kewajiban adil terhadap Tuhan.

Ketuhanan dalam kerangka Pancasila mengungkapkan komitmen

Regan, Commentary on Aristotle's Politics, (Indianapolis/Cambridge: Hackett Publishing Company, Inc., 2007), III, 6.

${ }^{42}$ Prof. DR. H. Kaelan, Op.Cit., hlm. 399. 
bangsa Indonesia untuk menata kehidupan politik-publik atau dasar nilainilai moral universal agama-agama serta budi pekerti yang luhur. Krisis moral yang dihadapi masyarakat modern serta fenomena kebangkitan agama-agama dalam masyarakat sekuler membuat paradigma Ketuhanan dalam kerangka Pancasila menjadi penting dan semakin relevan. $^{43}$

\section{Kritik bagi patologi liberalisme} Pemaknaan keadilan Pancasilais dalam terang pemikiran St. Thomas Aquinas kiranya dapat dipandang sebagai sebuah catatan kritis atas patologi masyarakat liberal dan memunculkan beberapa rujukan positif untuk sebuah kehidupan bersama. Dalam konteks diskursus teori keadilan modern, upaya untuk merekonstruksi relevansi pemaknaan konsep keadilan (iustitia) bagi Sila V Pancasila berada dalam lajur diskursus teori keadilan komunitarisme yang secara konseptual mengkritik dominasi teori keadilan liberalisme.

${ }^{43}$ Otto Gusti Madung, Filsafat Politik; Negara dalam Bentangan Diskursus Filosofis, (Maumere: Ledalero, 2013),hlm. 204.

${ }^{44}$ Otto Gusti Madung, "Pancasila, Demokrasi Liberal dan Komunitarisme", dalam Jurnal Ledalero; Wacana Iman dan Kebudayaan, Gerakan Sosial Untuk
Keadilan dalam pemikiran St. Thomas Aquinas selalu berhubungan secara primer dengan relasi sosial manusia. Teori keadilan komunitarisme juga memberikan aksentuasi pada sosialitas manusia. Dan, seperti antropologi komunitarian, Pancasila juga memberikan penekanan pada dimensi sosial hidup manusia. ${ }^{44}$

Menurut komunitarisme, liberalisme memandang manusia sebagai individu yang terisolasi dalam satu ruang kecil yang terlindungi, mengejar kebaikannya sendiri melalui caranya sendiri-sendiri. ${ }^{45}$ Kecenderungan untuk menekankan hak individu jika mengabaikan tuntutantuntutan sosial dalam bingkai hidup yang baik demi prospek bonum commune akan berdampak pada individualisme dalam kehidupan sosial yang justeru mengancam kebersamaan. St. Thomas Aquinas sendiri menekankan bahwa kebaikan pribadi harus diletakkan di bawah kepentingan umum. Baginya, keadilan selalu terarah pada bonum commune.

Perubahan Sosial, Vol. 13, No. 2, Desember 2014, Maumere, STFK Ledalero, hlm. 318.

${ }^{45}$ Jonathann Wolff, An Introduction to Political Philosophy, diterj. oleh M. Nur Prabowo Setyabudi dalam Pengantar Filsafat Politik, (Bandung: CV Nusa Media, 2013), hlm. 211. 
Setelah era reformasi, Indonesia mulai terbuka terhadap pandangan liberal yang melihat perkara hak asasi manusia dan kebebasan sebagai unsur-unsur penting dalam membangun kesejahteraan bersama. Namun, arus liberalisme yang cenderung bersifat individualis, bertentangan dengan semangat hidup bangsa Indonesia yang bersifat kekeluargaan. Adanya fenomena individualisme mulai menggerogoti masyarakat Indonesia. Penekanan pada aspek hak akhirnya juga mengikis rasa solidaritas dan nasionalisme. Kebebasan lebih mengarah pada anarkisme yang berujung pada kekerasan.

Patologi liberalisme yang dewasa kini menggerogoti masyarakat Indonesia juga telah merongrong kesadaran kolektif akan Pancasila sebagai identitas kolektif seluruh rakyat Indonesia. Lemahnya kesadaran akan tuntutan etis untuk menghidupi kebaikan bersama menunjukkan lemahnya solidaritas sosial. Belajar pada pemikiran St. Thomas Aquinas tentang keadilan yang mengarah pada bonum commune dan spiritualitas Pancasila dengan penekanan pada asas kekeluargaan, kiranya dapat membantu masyarakat Indonesia modern untuk mengkritisi bahaya individualisme dari masyarakat liberal.

\section{Kesimpulan}

Memperhadapkan konsep keadilan (iustitia) St. Thomas Aquinas dengan konsep keadilan dalam Pancasila merupakan sebuah gagasan untuk menghidupi dan memaknai Pancasila sebagai ideologi terbuka. Pergulatan intelektual untuk menemukan titik temu relevansi pemikiran menjadi upaya untuk mengangkat kembali nilai-nilai luhur Pancasila dalam diskursus intelektual. Relevansi pemaknaan nilai keadilan dalam kehidupan sosial kemasyarakatan di Indonesia, seperti diskurus keadilan dan hukum, kedilan dan politik, keadilan dan agama, serta relevansi kritis atas patologi liberalisme merupakan butirbutir relevansi pemikiran yang dapat dijadikan medan refleksi bagi kehidupan bangsa dan negara Indonesia demi terwujudnya bonum commune.

Pemaknaan nilai-nilai Pancasila sebagai identitas bangsa dan negara Indonesia merupakan ihwal yang sangat urgen, khususnya dalam fenomena mengikisnya kesadaranakan identitias kolektifnya sendiri. Chantal Mauffe ingin 
memberikan awasan kritis bahwa tak pernah ada identitas yang sudah selesai. Yang ada adalah proses konstruksi identitas kolektif yang tak pernah berakhir. "Niemals Identität, immer Identifizierungen; Tak penah ada identitas, tapi proses identifikasi." Upaya untuk menggali relevansi konsep keadilan (iustitia) St. Thomas Aquinas terhadap pemaknaan sila V Pancasila ini dapat dibaca sebagai sebuah konstruksi terhadap identitas bangsa Indonesia, yang perlu terus-menerus dihidupi dan dimaknai sebagai sebuah proses identifikasi.

\section{Daftar referensi}

Agustinus, De Moribus Ecclesiae Catholicae, trans. by Rev. Richard Stothert, M.A, The Morals of Catholic Church, in Philip Schaft, Nicene and Post-Nicene Fathers Series I Volume 4, Grand Rapids, MI: Christian Classic Ethereal Library yang diakses dari www.ccel.org/ccel/shaft/npnf.1024. html as we found it on 24 Juli 2015 12:08:51.

Arsitotle, Nichomacean Ethics, New York: Oxford University Press, 1998.

Bigongiari, Dino (ed.), The Political Ideas of St. Thomas Aquinas, New York: Hafner Publishing Company, Inc, 1953.
De Aquino, Sancti Thomae,Summa Theologiae IIaIIae, cum textu ex Recensione Leonina, Italy: Marietti Editori Ltd, 1962.

Summa

Theologica (Vol. II-III), translated by the Fahters of the English Dominican Province, New York: Benziger Brothers, 1948.

Summa Contra Gentiles, Textum Leonium emandatum ex plagulis de prelo Taurini 1961.

Commentary on Aristotle's Politics, Translated by Richard J. Regan, Hackett Publishing Company, Inc.,: Indianapolis/Cambridge, 2007.

Dyson, R.W, Aquinas Political Writings, New York: Cambridge University Press, 2002.

Jegalus, Norbertus, Hukum Kata Kerja; Diskursus Filsafat tentang Hukum Progresif, Jakarta: Obor, 2011.

Kaelan, H.,Negara Kebangsaan Pancasila; Kultural, Historis, Filosofis, Yuridis, dan Aktualisasinya, Yogyakarta:

Paradigma, 2013.

Madung, Otto Gusti,Filsafat Politik; Negara dalam Bentangan Diskursus Filosofis, Maumere: Ledalero, 2013.

Notonagoro, Pancasila Secara Ilmiah Populer, Jakarta: Pantjuran Tujuh, 1975.

Peschke, Karl-Heinz,Etika Kristiani; Jilid

III Kewajiban Moral dalam Hidup Pribadi, Maumere: Ledalero, 2003. Schmandt, J. Hendry, Filsafat Politik, Yogyakarta: Pustaka Pelajar, 2002 Spiazzi, Raimondo, Principi Di Etica Sociale, Bologna-Italia: PDUL 
Edizioni Studio Domenicano, 1989.

Sumaryo, E, Etika Profesi Hukum, Yogyakarta: Kanisius, 1995.

Weithman, J. Paul, "Complementarity and Equality in The Political Thought of Thomas Aquinas," dalam Michael A. Fahey, SJ, et. al., (eds.), Theological Studies, Vol. 59, No. 2, Juni 1998.

Wolff, Jonathan, An Introduction to Political Philosophy, diterj. oleh:

M. Nur Prabowo Setyabudi dalam Pengantar Filsafat Politik, Bandung: CV Nusa Media, 2013. 
LUMEN VERITATIS: Jurnal Filsafat dan Teologi, Volume. 12, Nomor 1, Oktober 2019 pSSN 1978-3469; eISSN 2657-1927 